\title{
Insulin and insulin like growth factor II endocytosis and signaling via insulin receptor $\mathrm{B}$
}

\author{
Jimena Giudice ${ }^{1,2,6}$, Lucia Soledad Barcos ${ }^{1}$, Francisco F Guaimas' ${ }^{1}$ Alberto Penas-Steinhardt ${ }^{3}$, Luciana Giordano ${ }^{4}$, \\ Elizabeth A Jares-Erijman ${ }^{2^{\wedge}}$ and Federico Coluccio Leskow ${ }^{1,5^{*}}$
}

\begin{abstract}
Background: Insulin and insulin-like growth factors (IGFs) act on tetrameric tyrosine kinase receptors controlling essential functions including growth, metabolism, reproduction and longevity. The insulin receptor (IR) binds insulin and IGFs with different affinities triggering different cell responses.

Results: We showed that IGF-II induces cell proliferation and gene transcription when IR-B is over-expressed. We combined biotinylated ligands with streptavidin conjugated quantum dots and visible fluorescent proteins to visualize the binding of IGF-II and insulin to IR-B and their ensuing internalization. By confocal microscopy and flow cytometry in living cells, we studied the internalization kinetic through the IR-B of both IGF-II, known to elicit proliferative responses, and insulin, a regulator of metabolism.

Conclusions: IGF-II promotes a faster internalization of IR-B than insulin. We propose that IGF-II differentially activates mitogenic responses through endosomes, while insulin-activated IR-B remains at the plasma membrane. This fact could facilitate the interaction with key effector molecules involved in metabolism regulation.
\end{abstract}

Keywords: Insulin / IGF-II, Insulin receptor, Microscopy, Quantum dots, Endocytosis, Signaling

\section{Lay abstract}

Background: The insulin receptor (IR) responds to insulin and IGF-II regulating glucose metabolism, cellular growth and differentiation. Results: Using quantum dotconjugated IGF-II and insulin we analyzed IR-B endocytosis in correlation with mitogenicity of each ligand. Conclusions: IGF-II promotes a fast IR internalization favoring mitogenic signaling whereas insulin-activated IR would endures signaling from the membrane. Significance: Ligand-specific redistribution of activated IR ensures signal specificity.

\section{Background}

Insulin and insulin-like growth factors (IGFs) are polypeptide hormones common to all metazoans [1]. They control essential functions including growth, metabolism,

\footnotetext{
* Correspondence: federico@fbmc.fcen.uba.ar

Deceased

'Departamento de Química Biológica, Facultad de Ciencias Exactas y Naturales (FCEN), Universidad de Buenos Aires (UBA), IQUIBICEN, CONICET,

Buenos Aires, Argentina

${ }^{5}$ Departamento de Ciencias Básicas, Universidad Nacional de Luján, Argentina

Full list of author information is available at the end of the article
}

reproduction and longevity which are triggered by activation of tetrameric tyrosine kinase receptors [2-9]. During vertebrate and invertebrate embryonic development, insulin and IGFs act as mitogenic growth factors. In postnatal vertebrates, insulin acts as a specialized metabolic hormone regulating glucose homeostasis, whereas IGFs retain their mitogenic functions. Invertebrates possess several insulin-like growth factors genes but only one receptor, DAF-2 [2,10-12]. In contrast, vertebrates express 3 hormone peptides (insulin, IGF-I and IGF-II) and 3 distinct DAF-2 homologous genes: the insulin receptor (Ir) $[13,14]$, the IGF-I receptor (Igf1r) [15] and the orphan receptor IR related receptor (Irr) [16,17]. Moreover, the mammalian Ir gene acquired an alternative exon and the ability to regulate its inclusion in a developmental and tissue specific manner. Exon 11 skipping leads to the ancestral IR-A [14], whereas its inclusion leads to the novel IR-B [13]. IR splicing appears altered in aging and in different pathologic states such as type 2 diabetes mellitus and myotonic dystrophy and cancer [18-20].

IGF-I and IGF-II are produced primarily by the liver. IGF-I biosynthesis tightly correlates with the circulating levels of growth hormone, such that Igf1 gene expression 
increases 10- to 100-fold between birth and adulthood [21]. Although the biological functions of IGF-I and IGF-II are similar in mammals, in humans circulating IGF-II exceeds IGF-I levels throughout post-natal life. IGFs bind to the IGF-IR, expressed in almost all cell types, promoting cellular growth and proliferation and inhibiting apoptosis. These growth factors stimulate DNA synthesis and regulate development and differentiation in a large variety of cell types, thus playing a key role in the maximum size acquired by an organism. For example, the extreme variability in the size of dogs (the greatest of any vertebrate) is due to polymorphisms present in the Igf1 gene [22]. It was also shown that a population carrying mutations in the growth hormone receptor gene has lower expression levels of the growth hormone receptor and IGF-I, while exhibiting a very low incidence of cancer and absence of diabetes [23].

The IR and IGF-IR share more than $50 \%$ sequence identity and up to $85 \%$ in their kinase domain [15,24]. IGF-IR and IR have a conserved modular protein structure $[15,25]$, being able to bind both insulin and IGFs. However, since IGF-IR shows higher affinity for IGF-I and IR for insulin, it is well accepted that insulin metabolic effects are mediated by IR whereas growth stimulation is due to IGF-IR signaling [1].

Almost all mammalian cells express either IR or IGFIR but at different levels [26-28]. When the two receptors are co-expressed, pro-receptors heterodimerize in the Golgi leading to hybrid receptors IR/IGF-IR [29-33], which presumably would be responsible for the cellular responses to IGF-I, IGF-II and insulin. It has been proposed that hybrid receptors are involved in insulin resistance in type 2 diabetes by lowering the number of hormone binding sites. In addition, a large fraction of hybrid receptors increases the binding sites for IGFs, a situation associated with a number of different types of cancer $[27,34]$.

The above body of information reinforces the importance of understanding the differences between the signaling triggered by different ligands through the axes IR/ IGF-IR. The affinities of insulin, IGF-I and IGF-II for IRA and IR-B as well as for IGF-IR and hybrid receptors have been studied by different groups with contradictory results $[27,33,35,36]$.

In the present study we analyzed the dynamics of signaling and endocytosis of IR-B after stimulation with insulin and IGF-II. We hypothesized that insulin and IGF-II would exhibit different endocytosis dynamics and that these differences would give new insights on the divergence of signaling pathways that could be triggered from the same receptor upon binding of different ligands. We combined techniques that allowed us to study and visualize individual cells by microscopy and flow cytometry. We tracked insulin and IGF-II endocytosis in living cells by using biotinylated ligands conjugated with streptavidin fluorescent nanoparticles (quantum dots or QD). Insulin and IGF-II promoted different endocytosis dynamic of IR-B, suggesting a mechanism for the divergent signaling pathways that can be trigger from a same receptor upon binding different ligands.

\section{Results}

\section{IGF-II induces IR-B phosphorylation}

We evaluated the effect of IGF-II on IR-B activation by confocal microscopy and Western blot. HeLa cells were transfected with pcDNA3-IR-B, serum starved and stimulated with $100 \mathrm{nM}$ human IGF-II or recombinant human insulin (rhIns) for $5 \mathrm{~min}$ at $37^{\circ} \mathrm{C}$. Lysates were assayed by Western blot, showing that IR-B responds to IGF-II and to rhIns (Figure 1A). Immunoblotting was carried on using a general antibody against phosphorylated tyrosine (PY20). The activation signal upon ligand binding was only present in cells over-expressing IR-B showing a band of the correct size of the $\beta$-subunit of the insulin receptor $(\sim 95 \mathrm{kDa})$. Figure $1 \mathrm{~B}$ shows a representative Western blot where the cells were transfected with the empty pcDNA3 (EV) showing that the levels of endogenous IR were almost not detected, neither its phosphorylation.

We evaluated HeLa endogenous levels of IR-A and IRB by reverse transcription and PCR (RT-PCR) observing a $24 \% \pm 6 \%$ exon 11 inclusion (Additional file 1: Figure S1A). This is consistent with HeLa's tumor origin and the reports showing a switch in the ratio of IR-A/IR-B in cancer cells [23,33,37]. Endogenous levels of IR and IGF-IR mRNA were measured by RT-PCR and normalized to GADPH mRNA showing a mRNA relative abundance of $1.1 \% \pm 0.4 \%$ for IR and $8.1 \% \pm 1.0 \%$ for IGF-IR (Additional file 1: Figure S1B). Correct identity of overexpressed IR-B was analyzed by sequencing and PCR (Additional file 1: Figure S1C).

In order to discriminate the contribution of the transfected IR-B from the endogenous receptors we measured IR activation in single cells expressing IR-B fused with the super cyan fluorescent protein (SCFP) (IR-B-SCFP) by immunofluorescence using a specific antibody against phosphorylated IR- $\beta$ subunit (Tyrosine 1361). We detected activation of IR-B at the plasma membrane after stimulating with $100 \mathrm{nM}$ IGF-II or rhIns (Figure 1C). Non-transfected cells did not show any activation signal (pointed with arrows in Figure 1C). Signal colocalization between IR-B-SCFP and phosphorylated IR- $\beta$ confirms that receptor activation triggered by ligand binding is originated from the over-expressed IR-B (Figure 1D).

We next estimated IR transfection efficiency ranging between 30 and $60 \%$ by microscopy using DIC (total cells) and fluorescence (transfected) images ( $n=219$ cells for IR fused to visible fluorescent proteins (VFP) and 


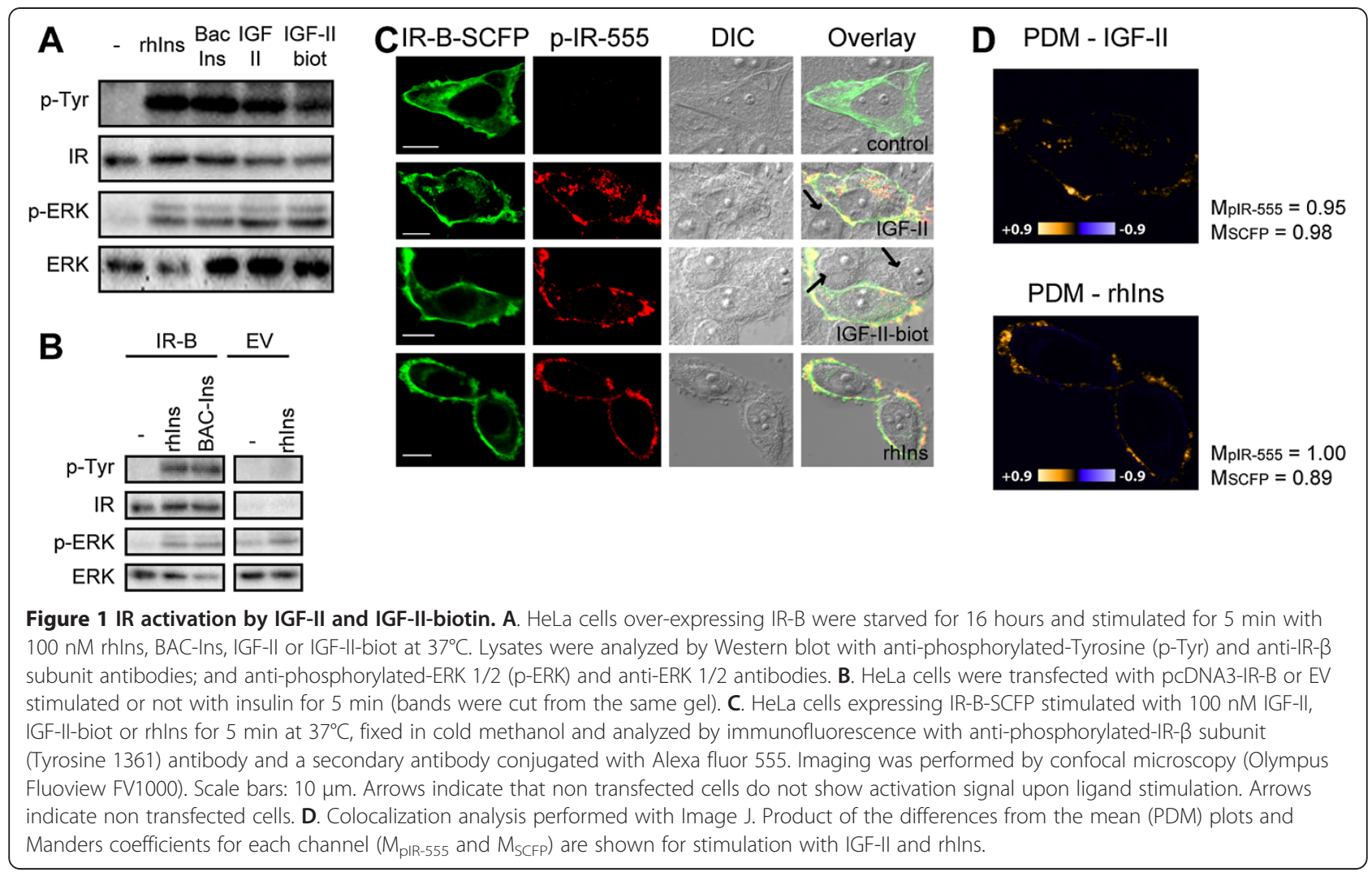

$n=308$ cells for IR from at least 3 images from 3 independent experiments) (Additional file 2: Figure S2).

\section{IGF-II induces cell proliferation through IR-B}

It is known that IGF-II is a mitogenic ligand for the IR $[37,38]$. In order to evaluate insulin and IGF-II-induced proliferation though IR-B, cells transfected with pcDNA3IR-B or the EV were starved with $1 \%$ FBS overnight and then treated with vehicle or $0.1 \mathrm{nM}, 1.0 \mathrm{nM}$ or $10.0 \mathrm{nM}$ IGF-II or rhIns for 2 days after which cell proliferation was measured by a non-radioactive assay. Data was normalized to those obtained with vehicle treated cells. Cells transfected with EV did not show any dependence on ligand concentration (Figure 2). This result suggests negligible contribution of the endogenous levels of IR and IGFIR in this proliferation assay. In contrast, both insulin and IGF-II induced a proliferative response in a dose dependent manner in IR-B over-expressing cells (Figure 2) (insulin: $1.3 \pm 0.1$ for $0.1 \mathrm{nM}, 1.9 \pm 0.2$ for $1.0 \mathrm{nM}$ and $2.1 \pm$ 0.1 for $10.0 \mathrm{nM}$; IGF-II: $1.4 \pm 0.2$ for $0.1 \mathrm{nM}, 2.1 \pm 0.3$ for $1.0 \mathrm{nM}$ and $2.4 \pm 0.3$ for $10.0 \mathrm{nM}$ ). In both cases these results were statistical different than those obtained in cells transfected with EV.

These data suggest that IGF-II induces cell proliferation via IR-B. Although a higher proliferative response was observed for IGF-II as compare to insulin,
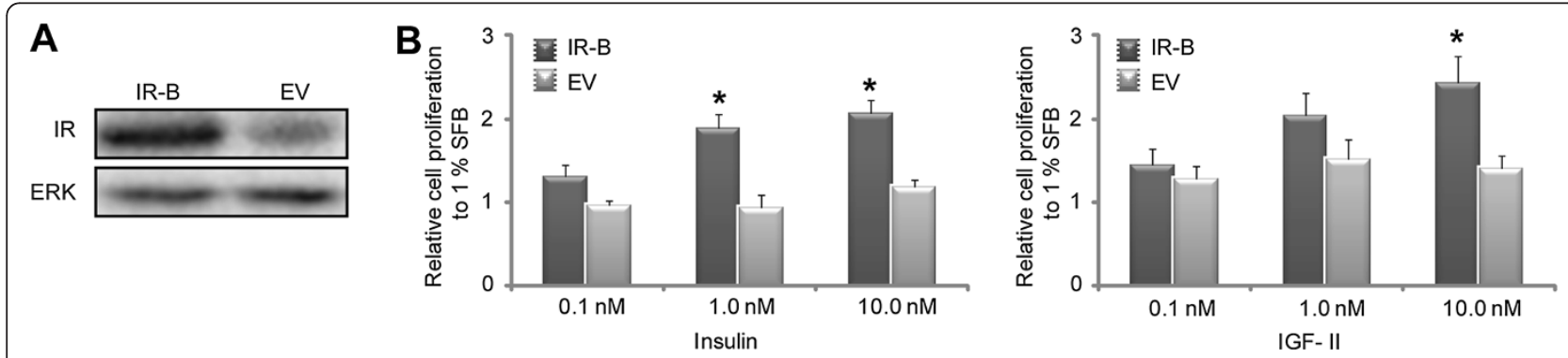

Figure 2 Proliferative response of IGF-II and rhIns through IR-B. A. HeLa cells transiently transfected with pcDNA3-IR-B or EV were assayed by Western blot detecting the expression of IR and ERK 1/2 (loading control). B. MTS assay in cells transiently transfected with pcDNA3-IR-B or EV stimulated with $0.1 \mathrm{nM}, 1.0 \mathrm{nM}$ and $10.0 \mathrm{nM}$ IGF-II or rhlns for 2 days. The results are shown as the mean \pm s.e.m $(n=3$ independent experiments). Asterisks indicate significant differences between IR and EV $(p<0.05)$. 
the differences between both ligands were not statistically significant.

\section{IGF-II induces AP-1 dependent gene transcription through IR-B}

We measured AP-1 dependent gene transcription using a Luciferase reporter assay in cells over-expressing IR-B (Figure 3A). For this purpose, first we evaluated the effects of IGF-II and insulin on endogenous receptors. HeLa cells are derived from an epithelial tumor and are well known to respond to the epidermal growth factor (EGF), that can be suitably used as a positive control (Figure 3B). No effect on gene transcription was observed upon stimulation with IGF-II and/or rhIns. These results confirm an insignificant contribution of endogenous IR and IGF-IR. Next, we evaluated, in IR-B expressing HeLa cells, the effects of EGF in combination with IGF-II or rhIns on AP-1 induction. IR-B over-expressing cells showed a significant response to rhIns and IGF-II, without affecting EGF induction (Figure 3C, right). Costimulation with EGF and rhIns showed an additive effect on AP-1 induction, suggesting that both ligands activate AP-1 through different pathways. This response was statistically different from rhIns alone $(p \leq 0.005)$. In contrast, cells treated with rhIns + IGF-II did not exhibit a combined response, indicating that these ligands induced AP-1 through the same receptor (Figure 3C, left).

\section{Imaging of ligand-receptor complexes endocytosis}

In order to visualize the ligand receptor endocytosis using QD, commercially available biotinylated ligands, biotin amido caproyl insulin (BAC-Ins) and IGF-II-biot, were used [39]. We confirmed by Western blot and immunofluorescence that BAC-Ins and IGF-II-biot were capable of activating IR-B (Figure 1A-B). To visualize the receptor we used IR-B fused with different VFPs. These proteins localized properly at the plasma membrane and were positively stained with two different antibodies against regions of the $\mathrm{N}$-terminus of the $\alpha$-subunit of IR (N20 and H78) (Additional file 3: Figure S3).

The two step labeling strategy is schematically summarized in Figure 4A. Briefly, live HeLa cells expressing IR$\mathrm{B}$ were treated at $15^{\circ} \mathrm{C}$ or room temperature with biotinylated ligands for $15 \mathrm{~min}$. After washing the free ligand, cells were incubated $10 \mathrm{~min}$ with streptavidin conjugated QD655 (QD with emission peak at $655 \mathrm{~nm}$ ), washed to remove unbound QD655 and incubated at $37^{\circ} \mathrm{C}$ for different time periods.

To evaluate the optimal QD655 concentration, HeLa cells expressing IR-B-GFP were incubated with $50 \mathrm{nM}$ BAC-Ins followed by variable concentrations of QD655 (Figure 4B). Cells were fixed with PFA and imaged by confocal microscopy. Control cells without previous incubation with BAC-Ins did not show any signal (Figure 4B, first column). We calculated the ratio between QD655 and GFP signals (see Methods) observing a dose response

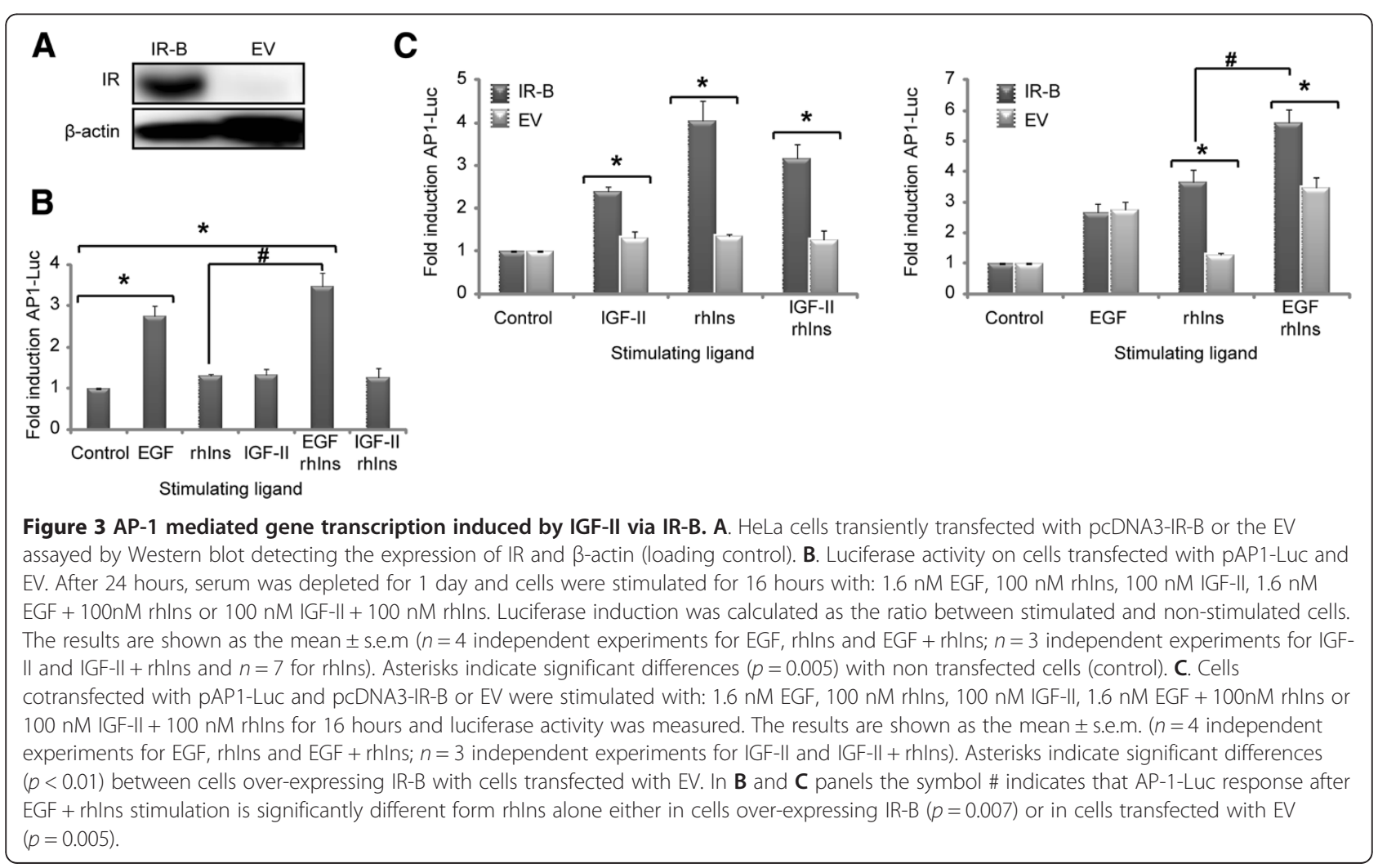




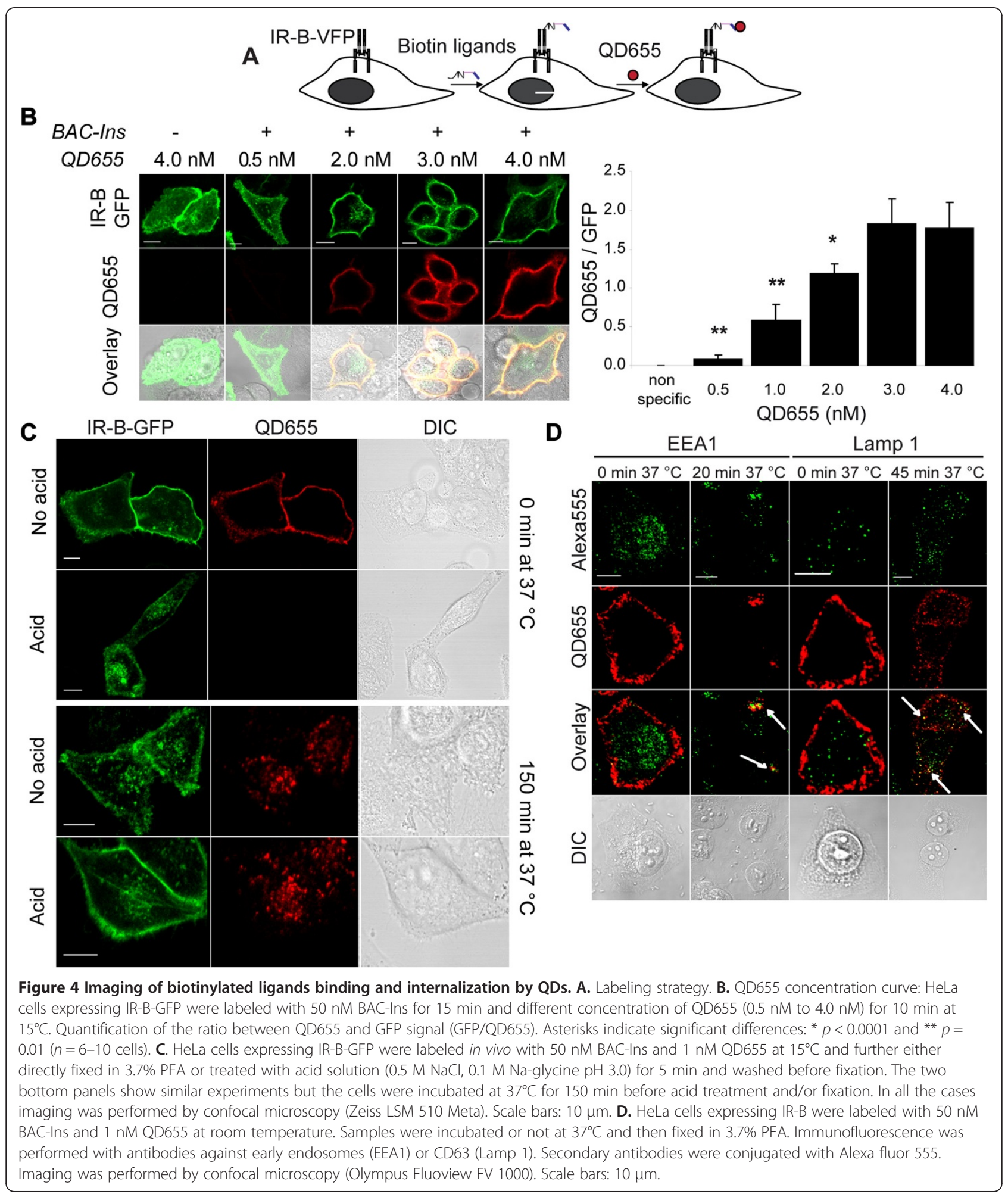

curve. These ratios were significantly different $(p \leq 0.01)$. From these results a non saturating concentration of 1 nM QD655 was chosen for further work

The internalization of IR-B-GFP in living cells was analyzed by sequentially labeling HeLa cells with $50 \mathrm{nM}$
BAC-Ins and $1 \mathrm{nM}$ QD655. Cells were directly fixed in 3.7\% PFA or incubated at $37^{\circ} \mathrm{C}$ for $150 \mathrm{~min}$ before fixation (Figure 4C). At the beginning GFP and QD655 signals colocalized at the plasma membrane. By contrast, after 150 min at $37^{\circ} \mathrm{C}$ the majority of QD655 signal was located in 
the cytoplasm, in the perinuclear region. In order to confirm the internalization, cells were treated with an acid solution (0.5 M NaCl, 0.1 M Na-glycine $\mathrm{pH} 3.0$ ) for $5 \mathrm{~min}$ and washed before fixation. Acid would induce the dissociation between ligand and receptor at the cell surface [40]. These experiments showed that, while in samples that were not incubated at $37^{\circ} \mathrm{C}$ the acid treatment removed completely QD655 signal (without affecting IR-B -VFP signal), cells incubated at $37^{\circ} \mathrm{C}$ maintained the internalized QD655 signal. To evaluate whether the size or the nature of the nanoparticles could be affecting the observed results, similar experiments were performed but treating cells with $50 \mathrm{nM}$ BAC-Ins and sequentially with $1 \mathrm{nM}$ fluorescent streptavidin (SA-atto 550) (Additional file 4: Figure S4A). Additionally, cells were directly incubated with $50 \mathrm{nM}$ fluorescently labeled insulin (FITC-insulin) (Additional file 4: Figure S4B). Although brightness and photostability were compromised, both strategies showed a similar labeling pattern as compare to QD655 either at the onset or after internalization.

In order to trace the insulin-IR endocytic pathway we performed immunofluorescence experiments using early endosomes (EEA1) and lysosome markers (Lamp 1). After 20 min, co-localization between QD655 and early endosomes was observed while at $45 \mathrm{~min}$, the QD655 signal was mainly located at perinuclear lysosomes (Figure 4D).

\section{Visualization of IGF-II bound to IR-B and its endocytosis}

We have previously shown that IGF-II and IGF-II-biot induce IR-B activation followed by ERK $1 / 2$ phosphorylation,

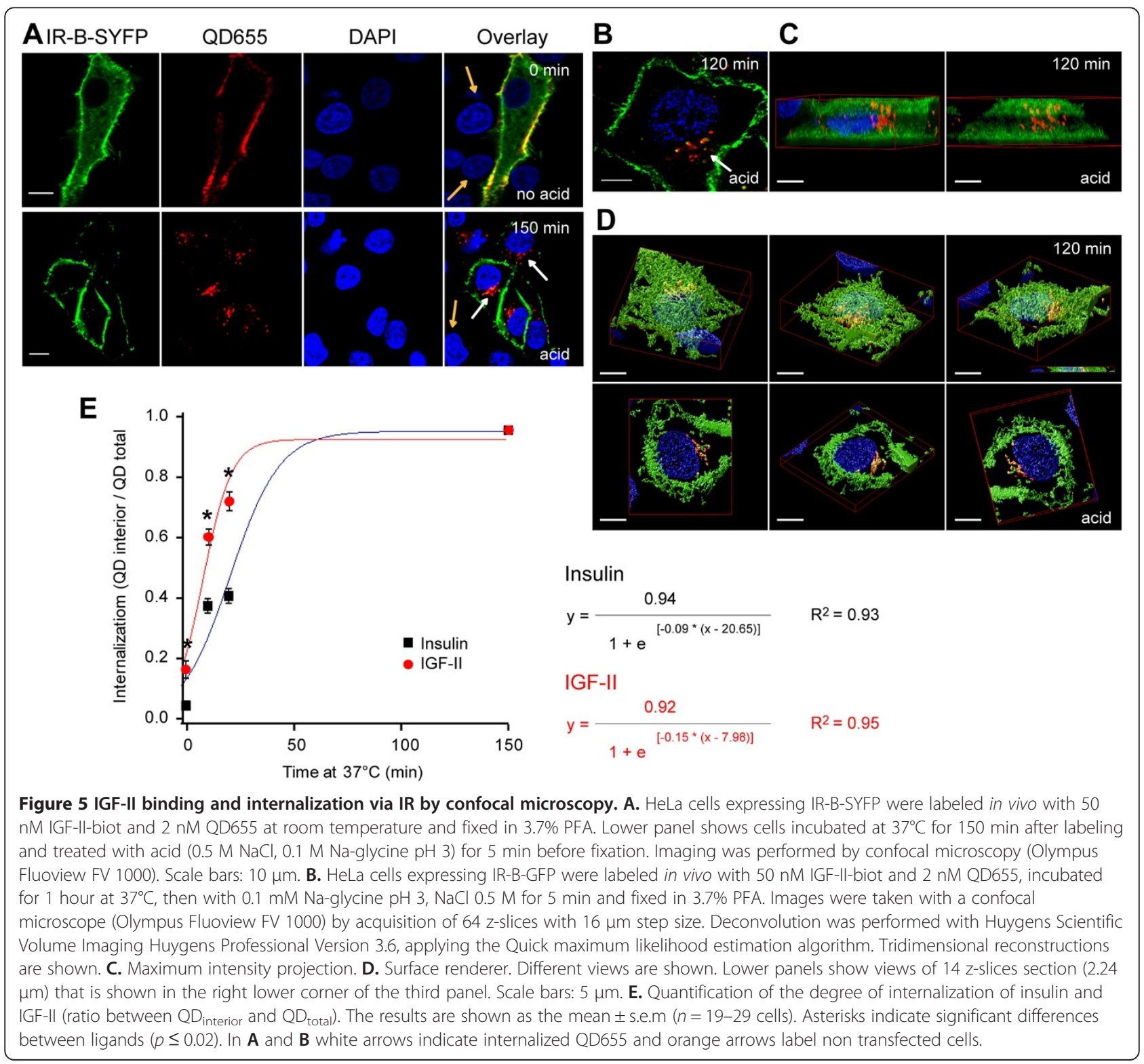


AP-1 gene transcription and cell proliferation. To study IGF-II induced endocytosis of IR-B in individual cells, HeLa cells expressing IR-B-SYFP were incubated with $50 \mathrm{nM}$ IGF-II-biot for $15 \mathrm{~min}$ and labeled with $1 \mathrm{nM}$ QD655 for $10 \mathrm{~min}$ at room temperature. Confocal microscopy revealed that IGF-II bound specifically to IR-B-SYFP: no signal was detected in non-transfected cells (Figure 5A, arrows). When cells were incubated at $37^{\circ} \mathrm{C}$ for 150 min after labeling, internalization of IGF-II-QD655 was detected only in transfected cells. Internalization was confirmed by exposure of the cells to an acidic solution ( $5 \mathrm{~min}, 0.5 \mathrm{M} \mathrm{NaCl}, 0.1 \mathrm{M}$ Na-glycine $\mathrm{pH}$ 3.0) before fixation. The data demonstrates that ligand-QD complexes were exclusively localized at the plasma membrane and internalized only after subsequent incubation at $37^{\circ} \mathrm{C}$. QD655 signal was only detected inside the cell (Figure 5A, second row panels). The intracellular localization of IGF-II-QD655 complexes was assessed in more detail by optical sectioning. We acquired 64 confocal $z$-slices with a $16 \mu \mathrm{m}$ step size of cells expressing IR-B-GFP labeled as described above, incubated for $150 \mathrm{~min}$ at $37^{\circ} \mathrm{C}$ and treated for $5 \mathrm{~min}$ with acid before fixation. Deconvolution of the images by a Quick Maximum Likelihood Estimation (QMLE) algorithm and tridimensional reconstruction of the cells evidenced the presence of IGF-IIQD655 in the perinuclear region partially co-localizing with IR-B-GFP (Figure 5B-D and Additional file 5: Movie S1).

\section{Kinetics of IGF-II and insulin internalization by microscopy} The kinetics of ligand internalization of IGF-II and insulin was quantified by labeling HeLa cells expressing IR-B-SYFP with $50 \mathrm{nM}$ IGF-II or BAC-Ins and $1 \mathrm{nM}$ QD655 and further incubating at $37^{\circ} \mathrm{C}$ for 10,20 or 150 min. QD655 signal inside the cells increased over time, indicating that endocytosis had taken place (Figure 5A). The extent of endocytosis was quantified after segmentation of each cell into membrane and interior, calculating the ratio between the signal from the cytosol ( $\left.\mathrm{QD}_{\text {interior }}\right)$ over the total $\left(\mathrm{QD}_{\text {total }}=\mathrm{QD}_{\text {interior }}+\mathrm{QD}_{\text {membrane }}\right)$ (ratio: $\mathrm{QD}_{\text {interior }} / \mathrm{QD}_{\text {total }}$ ) using image processing tools on individual cells at different time points (See Methods) (Figure 5E). Only cells with similar IR-B-SYFP expression levels (estimated by the VFP intensity signal) were considered since high expression levels of IR affect internalization rates (data not shown). The data indicate that IGF-II internalized faster than insulin through IR-B. After short incubation at $37^{\circ} \mathrm{C}$ the fraction of internalized IGF-II-biot-QD655 (10 $\mathrm{min}: 0.60 \pm 0.03$; $20 \mathrm{~min}$ : $0.72 \pm 0.03 ; n=20$ cells) was significantly higher than that of BAC-Ins-QD655 (10 min: $0.38 \pm 0.03$ and 20 min: $0.41 \pm 0.03 ; n=10-20$ cells) in cells over-expressing IR-B $(p<0.00001)$. Differences between both ligands were also significant at the onset of the experiment. While insulin internalization at room temperature is negligible $(0.06 \pm 0.01)$, IGF-II is significantly endocytosed
$(0.17 \pm 0.03)(p=0.002 ; n=28-29$ cells $)$. Data were fitted to a sigmoideal curve (logistic) and the first derivative in each time point was calculated finding the maximal $\mathrm{k}$ $\left(\mathrm{k}_{\max }\right)$. This analysis showed a higher $\mathrm{k}_{\max }$ for IGF-II $\left((0.034 \pm 0.002) \mathrm{min}^{-1}\right)$ than for insulin $((0.021 \pm 0.001)$ $\left.\mathrm{min}^{-1}\right)$. At longer incubation times $(150 \mathrm{~min})$ both ligands are equally and almost completely internalized (IGF-II: $0.96 \pm 0.01$ and Insulin: $0.95 \pm 0.01 ; n=19-23$ cells) (see Table 1).

\section{IGF-II and insulin rate of internalization by flow cytometry} The results obtained by microscopy were confirmed measuring IGF-II internalization by flow cytometry detecting QD655 and SYFP signal. First, the specificity of QD655 binding to biotinylated ligands was evaluated in cells expressing IR-B or IR-B-SYFP and treated with QD655 with or without previous incubation with BACIns, showing that the number of events with high QD655 signal was significantly higher when BAC-Ins was added (Additional file 6: Figure S5). On the other hand, the population of events showing high QD655 intensity shifted to the right if the cells expressed IR-B fused to a fluorescent protein confirming that only transfected cells are binding BAC-Ins-QD655 (Additional file 6: Figure S5). We defined four regions according to fluorescence intensity and quantified the events inside region II (high SYFP and QD655 signals) in cells expressing IR-B-SYFP treated with QD655 with or without BAC-Ins. We normalized these data to control cells without transfection (fold with respect to the control: $1.1 \pm 0.1$ for cells treated only with QD655 and 5.4 \pm 0.3 for cells incubated with BAC-Ins and QD655; $n=3$ independent experiments, $p<0.0005$ ) confirming specific labeling (Additional file 6: Figure S5F).

After confirming that flow cytometry allows us to detect specific binding of biotinylated ligands to IR-B in living and individual cells, we tested whether acid treatment could remove receptor-bound ligands at the plasma membrane. Cells expressing IR-B-SYFP were labeled with IGF-II-biot and QD655 and incubated with acid for 2 min. Living cells were analyzed by flow cytometry quantifying SYFP and QD655 signals. We estimated the ratio between the number of events showing high QD655 and SYFP signals (quadrant II) over the total events with high SYFP signal (quadrants II + IV; i.e., transfected cells) before and after acid treatment. The analysis showed that acid treatment removes the IGF-II -biot-QD655 bound to IR at the plasma membrane (Additional file 6: Figure S5G). Similar experiments were performed by incubating labeled cells for 20, 40 and 90 minutes at $37^{\circ} \mathrm{C}$ prior to acid treatment. The data were first analyzed by selecting the events with high SYFP signal (transfected cells) and generating QD655 histograms. The histograms showed that longer incubation at $37^{\circ} \mathrm{C}$ increased the QD655 geometric mean values, validating 
Table 1 Internalization of IGF-II and insulin through IR-B by microscopy

\begin{tabular}{|c|c|c|c|c|c|c|c|c|}
\hline \multirow{2}{*}{$\frac{\text { Time at } 37^{\circ} \mathrm{C}}{\text { Ligand }}$} & \multicolumn{2}{|c|}{$0 \mathrm{~min}$} & \multicolumn{2}{|c|}{$10 \mathrm{~min}$} & \multicolumn{2}{|c|}{$20 \mathrm{~min}$} & \multicolumn{2}{|c|}{$150 \mathrm{~min}$} \\
\hline & Insulin & IGF-II & Insulin & IGF-II & Insulin & IGF-II & Insulin & IGF-II \\
\hline Average & 0.06 & 0.17 & 0.38 & 0.60 & 0.41 & 0.72 & 0.95 & 0.96 \\
\hline s.e.m & 0.01 & 0.03 & 0.03 & 0.03 & 0.03 & 0.03 & 0.01 & 0.01 \\
\hline$n$ & 28 & 29 & 10 & 20 & 20 & 20 & 23 & 19 \\
\hline$p$ (insulin versus IGF-II) & \multicolumn{2}{|c|}{$2 \mathrm{E}-03$} & \multicolumn{2}{|c|}{ 9E-06 } & \multicolumn{2}{|c|}{ 7E-09 } & \multicolumn{2}{|c|}{ 9E-01 } \\
\hline
\end{tabular}

Quantification of the degree of internalization of IGF-II and insulin in HeLa cells expressing IR-B-SYFP labeled in vivo with $50 \mathrm{nM}$ BAC-Ins and $1 \mathrm{nM}$ QD655 at room temperature.

the cellular means as measures of internalized IGF-IIbiot-QD655 (Figure 6A). While the geometric mean did not change in acid untreated cells, it did increase over the time in acid treated cells. Analysis of the histograms for IGF-II and insulin internalization over the time revealed a shift of the geometric mean of the QD655 signal (Figure 6B-C). We quantified the high QD655 signal events using a marker $M 1$ on each histogram including approximately $4 \%$ of the events at the time defined as zero $(0 \mathrm{~min})$. For each incubation point we determined the percentage of events inside the region $M 1$ and normalized it to the value obtained for the time defined as zero (Marker/0 min). According to the $M 1$ marker, a greater fraction of IR expressing cells internalized IGFII-biot-QD655 than BAC-Ins-QD655. These differences were statistical significant $(p=0.01)$ after short incubation times $(20 \mathrm{~min})$, confirming the faster internalization dynamics induced by IGF-II than by insulin (Figure 6D; insulin: $1.7 \pm 0.2$ and IGF-II: $2.6 \pm 0.2 ; n=4$ independent experiments). We fitted the data to a sigmoideal curve (logistic) and calculated the first derivatives. The analysis showed that the $\mathrm{k}_{\max }$ for IGF-II was higher $\left((0.08 \pm 0.02) \mathrm{min}^{-1}\right)$ than the $\mathrm{k}_{\max }$ for insulin $\left((0.06 \pm 0.01) \mathrm{min}^{-1}\right)$. In contrast, data from samples treated without acid did not show an increase over the time or a logistic fitting $\left(R^{2}=0.57\right)$.

\section{Discussion}

We showed that IGF-II is a potent IR-B ligand inducing cell proliferation and AP-1 mediated gene transcription. Luciferase reporter assays confirmed that IGF-II could signal specifically through transfected IR since overexpression of IR-B turns HeLa cells responsive to rhIns and IGF-II, without affecting the induction promoted by EGF. Furthermore, while co-stimulation with EGF and rhIns triggered an additive AP-1 induction, rhIns + IGFII did not exhibit a combined response. These results indicate that insulin and IGF-II induce AP-1 through the same IR/IGF-IR axis when IR is over-expressed, in contrast to EGF that signals independently.

The combination of IR-B fused to VFPs with biotinylated ligands as well as streptavidin conjugated QDs allow to visualize and quantitatively study IGF-II binding to the
IR-B and its ensuing endocytosis. This approach permits to study endocytosis by tracking the ligand-receptor complex discriminating the internalized receptors from the cytoplasmatic pool. To label the ligand-receptor complexes exclusively at the cell surface we used a combination of biotinylated ligands and streptavidin conjugated QDs. Although this could also be reached using fluorescent streptavidin instead of QDs or fluorescently modified ligands, QDs provide powerful advantages for imaging: (a) high and uniform brilliance, allowing robust quantification of binding and transport processes, (b) photostability which is crucial for long term experiments, (c) broad excitation spectrum, allowing the co-imaging with VFPs without bleed-through risk, (d) narrow emission band in the red part of the spectra well separated from the fluorescence of the VFPs and (e) proper biochemical stability and specificity and low background [40]. Specificity of QD internalization was corroborated since in the absence of biotinylated ligands no QD signal was detected. We showed that internalization process using biotinylarted ligands + QDs occurs similarly than when using fluorescent insulin or biotinylated ligands + fluorescent streptavidin. The internalization of the complexes through endocytosis was also confirmed by co-localization with endocytosis markers during the process.

Additionally, the effect of biotinylation over ligand activity was controlled, biotinylated-IGF-II triggered IR-B signaling activation to a similar degree than human IGFII measured as IR auto-phosphorylation and ERK 1/2 activation.

The endocytosis of IGF-II by IR-B exhibited to proceed with a faster kinetics than that of insulin measured both by confocal microscopy and flow cytometry. These techniques showed to be complementary since microscopy provides the advantage of visualizing the process in detail in individual cells and flow cytometry allows the analysis of a large number of events. By microscopy we measured internalization as the proportion of ligand-QD present inside individual cells expressing IR-B after different incubation times at $37^{\circ} \mathrm{C}$. Complimentary, by flow cytometry we counted the number of cells exhibiting internalized ligand-QD655 after stimulation. We calculated the rate of internalization at the onset as well as 


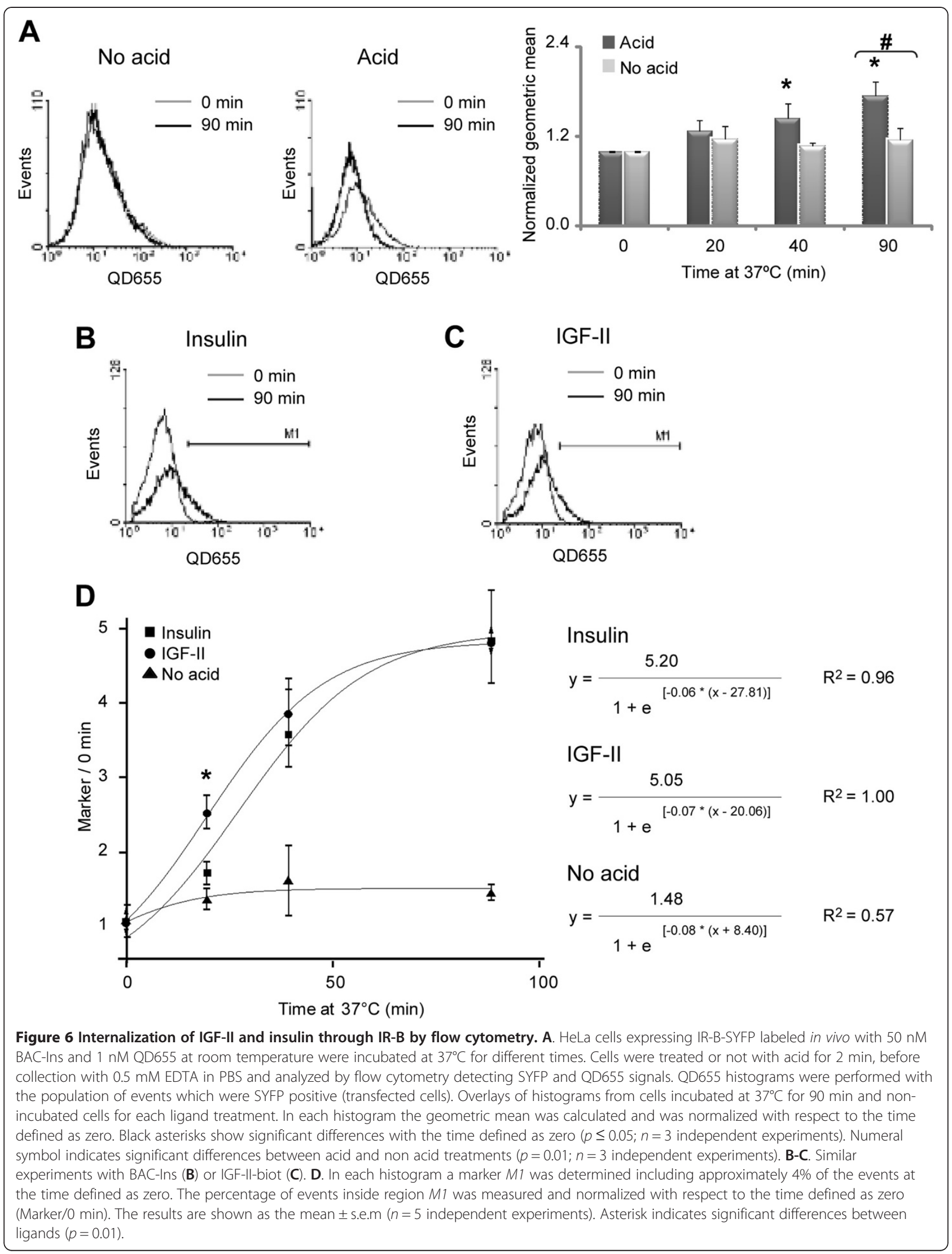


after 10 min of incubation at $37^{\circ} \mathrm{C}$ leading us to similar results obtained by others using radioactive experiments [41-43]. Some of these reports are discordant depending on the cells used or the method of analysis applied. While for insulin internalization Draznin and colleagues [41] reported a $\mathrm{k}=0.049 \mathrm{~min}^{-1}$ and a half time of 14.5 min, Knuston [44] discussed these results informing a $\mathrm{k}=0.0023$ and a half time of 4.9 hours. In our experiments, applying a completely different method, we obtain results closer to those reported by Draznin and colleagues [41]. In addition, our data confirm that, in IR-B over-expressing HeLa cells, IGF-II is internalized faster (half time $=20.3 \mathrm{~min}$ ) than insulin (half time $=$ $33.6 \mathrm{~min}$ ). Recently, Morrione et al. [45] showed that insulin and IGF-II regulate endocytic sorting and stability of the IR-A. They showed that IGF-II induces lower IR-A activation than insulin. However, this differential endocytic sorting would protect IR-A from downregulation, explaining a more sustained mitogenicity. This study shows, in an elegant manner, how one same receptor could be differentially regulated, triggering different signaling responses, after binding two different ligands. Although there are important discrepancies in the field, the overwhelming consensus is that IGF-II has low affinity for IR-B and high affinity for IR-A compared with that of insulin. We focused in the study of IR-B since this receptor is considered to be the one mostly responsible for the metabolic effect of insulin and we addressed its dynamics upon binding insulin (a metabolic regulator) and IGF-II (a mitogenic growth factor). Our interest was to address this open question in vivo and with new technologies that had not been applied yet to the insulin/IGF field.

\section{Conclusions}

The evidence presented here is consistent with the model of signal transduction divergence modulated by the cellular localization of receptor-ligand complexes [46-55]. Mitogenic ligand-receptor complexes are internalized more rapidly, thereby triggering signaling from endosomes; whereas ligand-receptor complexes retained at the plasma membrane lead to a more metabolic response. This view is in accordance with a variety of reports using different experimental approaches. For example, insulin analogs exhibiting different receptor dissociation rates indicate that faster dissociating analogs lead to a more sustained activation of the receptor and a more persistent activation of Shc $[53,56]$. On the other hand, longer signal duration at the level of the receptor leads to a mitogenic response of insulin [56-59] suggesting that mitogenic signaling is mediated by a more sustained activation of the IR. Additionally, noninternalizing IR mutants showed an enhancement of some biological responses to insulin and attenuation of others [52] and pharmacological inhibition of endocytosis demonstrate that the metabolic actions of insulin are largely independent of insulin receptor endocytosis and are initiated by activation of the plasma membranelocalized insulin receptor [40]. We improved the duality of the studied model using one receptor and two ligands: a mitogenic one (IGF-II) and a metabolic one (insulin).

\section{Methods}

\section{Materials}

rhIns was kindly provided by Laboratorios Beta (Buenos Aires, Argentina). IGF-II-biot was from IBT system (Reutlingen, Germany) and human recombinant IGF-II was from Gro Pep (Adelaide, Australia). BAC-Ins was from Sigma (Munich, Germany). Polyclonal rabbit antiERK2, polyclonal rabbit anti-CD63 (Lamp 1) and polyclonal rabbit anti-IR- $\alpha$-subunit (N20 and H78) were from Santa Cruz Biotechnology (Paso Robles, CA). EEA1 marker (rabbit) was from Abcam (Cambridge, MA). Monoclonal mouse anti-phosphorylated-tyrosine (PY20) was from BD Transduction Laboratories (Franklin Lakes, NJ). Monoclonal rabbit anti-phosphorylated-IR- $\beta$ subunit (Tyrosine 1361), monoclonal mouse anti-IR- $\beta$ subunit and polyclonal rabbit anti-phosphorylated (p42/ 44) MAPK were from Cell Signaling Technology (Beverly, MA). The monoclonal rabbit anti-phosphorylated-IR- $\beta$ subunit (Tyrosine 1361) from Cell Signaling (cat \# 3023) only detects transfected levels of IR $\beta$ subunit and slightly cross-reacts with activated IGF-I receptor. The streptavidin conjugated QD655 and secondary antibodies conjugated with Alexa fluor 555 were from Molecular Probes, Invitrogen (Eugene, OR). Streptavidin-atto 550 was from ATTO-TEC Gmbh (Siegen, Germany). Lipofectamine Reagent 2000, DNase I and Trizol were from Invitrogen (Carlsbad, CA). High Capacity cDNA Reverse Transcription kit was from Applied Biosystem (Foster City, CA). Cell Titer 96 Aqueous Non-Radioactive Cell Proliferation Assay (MTS) and Gotaq DNA polymerase were from Promega (Madison, WI). The plasmid containing the luciferase reporter gene downstream of seven binding sites for AP-1 (pAP-1-Luc) was provided by Dr. Omar Coso (IFIBYNE, Argentina).

\section{Plasmids generation}

pcDNA3-IR-B: cDNA of IR-B was provided by Dr. Axel Ullrich (Max Planck Institute for Biophysical Chemistry, Germany) and amplified by PCR using primers containing HindIII restriction site (IR-Forward: 5' aagcttatggccaccgggggccgg- $3^{\prime}$ ) and NheI and XbaI sites (IR-Reverse: 5 '-tctagagctagcgaaggattggaccgaggcaaggtc-3'). The product was digested with HindIII and XbaI enzymes and cloned into the pcDNA3 vector. $p c D N A 3-I R-B-G F P$, pcDNA3-IR-B-SCFP and pcDNA3-IR-B-SYFP: peGFP-C3 (Clontech), pSCFP-3AC or pSYFP-2F (provided by T. W. 
Gadella Jr., University of Amsterdam, The Netherlands) were digested with NheI and ApaI and cloned into pcDNA3-IR-B.

\section{Cell culture and transfections}

Cell culture reagents (Dulbecco's modified Eagle's medium (DMEM) Glutamax, Optimem, fetal bovine serum (FBS), trypsin and antibiotics) were from GIBCO (Grand Island, NE). HeLa cells were maintained in DMEM supplemented with penicillin, streptomycin and $10 \% \mathrm{FBS}$ at $37^{\circ} \mathrm{C}$ in $5 \% \mathrm{CO}_{2}$. Human cervical carcinoma HeLa cells (ATCCCCL-2) were plated at $1 \times 10^{5}$ cells/well in 24 well plates and onto $12 \mathrm{~mm}$ glass coverslips (for microscopy experiments) or at $2.5 \times 10^{5}$ cells/well in 12 wells plates (for Western blot experiments) one day before transfection in DMEM supplemented with 10\% FBS without antibiotics. Cells were transfected with Lipofectamine Reagent 2000 for 5 hours using $0.4 \mu \mathrm{g}$ DNA and $1 \mu \mathrm{l}$ Lipofectamine per well for 24 well plates and $0.8 \mu \mathrm{g}$ DNA and $2 \mu \mathrm{l}$ Lipofectamine per well for 12 well plates. After transfection cells were cultured for further expression in complete medium.

\section{Western blots}

Following stimulation with rhIns, BAC-Ins, IGF-II or IGF-II-biot cells were lysed in buffer containing $100 \mathrm{mM}$ Tris- $\mathrm{HCl}$ pH 6.8, 4\% SDS, 0.2\% bromophenol blue, 20\% glycerol, $200 \mathrm{mM} \beta$-mercaptoethanol, vortexed for 20 sec and heated $5 \mathrm{~min}$ at $100^{\circ} \mathrm{C}$. After $10 \%$ SDS-PAGE and transfer, membranes were blocked in $5 \% \mathrm{w} / \mathrm{v}$ nonfat dried milk in $0.1 \%$ Tween-TBS buffer (TTBS) for 1 hour, washed and incubated overnight at $4^{\circ} \mathrm{C}$ with primary antibodies diluted in $5 \%$ bovine serum albumin (BSA)/TTBS (anti-IR- $\beta$ subunit: 1/500, anti-ERK2: 0.2 $\mu \mathrm{g} / \mathrm{ml}$, anti-phosphorylated-p44/42 MAPK: 1/500) or in 2\% BSA/TTBS (anti-phosphorylated-Tyrosine: $2 \mu \mathrm{g} / \mathrm{ml}$ ). Membranes were incubated with secondary antibodies for 1 hour and washed with TTBS. The blots were developed by chemiluminescence with a Bio-Imaging Analyzer Bas-1800II and Image Gauge 3.12, FUJIFILM.

\section{Luciferase reporter assay}

Cells seeded onto 24 well plates $\left(1 \times 10^{5}\right.$ cells/well $)$ the day before were transfected using $0.3 \mu \mathrm{g}$ pcDNA3-IR or pcDNA3 (empty vector, EV) and $0.05 \mu \mathrm{g}$ pAP1-Luc. After 24 hours, cells were starved one day, and then stimulated for 16 hours with $1.6 \mathrm{nM}$ EGF, $100 \mathrm{nM}$ rhIns, $100 \mathrm{nM}$ IGF-II, $1.6 \mathrm{nM}$ EGF + 100nM rhIns or $100 \mathrm{nM}$ IGF-II + 100 nM rhIns. Luciferase activity was determined using Luciferase Reactive and Reporter Lysis Buffer from Promega (Madison, WI) and normalization to the control (non-stimulated cells) was performed (fold induction). The results were expressed as the mean of at least three independent experiments \pm s.e.m. The $p$ values were estimated using Student's $T$ test ( 2 tails).

\section{Cell proliferation experiments}

Cells were transfected with pcDNA3-IR or the EV, 24 hours after transfection they were treated with 1\% FBS overnight before stimulation with $0.1 \mathrm{nM}, 1 \mathrm{nM}$ or $10 \mathrm{nM}$ rhIns or IGF-II for 2 days. Cell proliferation was measured using a non-radioactive assay (MTS) according to manufacturer procedures. The results were normalized to those obtained for the cells incubated in 1\% FBS over all the experiments. The results were expressed as the mean of at least three independent experiments \pm s.e.m. The $p$ values were estimated using Student's $T$ test ( 2 tails).

\section{Labeling in vivo with QDs-IGF-II-biot or BAC-Ins and internalization}

Before the experiment cells expressing IR-B, IR-B-SYFP or IR-B-GFP were starved overnight, washed with Tyrode's buffer (135 mM NaCl, $10 \mathrm{mM} \mathrm{KCl,} 10 \mathrm{mM}$ $\mathrm{MgCl}_{2}, 1 \mathrm{mM} \mathrm{CaCl}, 10 \mathrm{mM}$ HEPES pH 7.2, 0.1\% BSA) at room temperature or $15^{\circ} \mathrm{C}$ (as indicated in figure legends) and incubated with $50 \mathrm{nM}$ BAC-Ins or IGF-II-biot for $15 \mathrm{~min}$, washed with Tyrode's and incubated with $0.5,1.0,2.0$ or $4.0 \mathrm{nM}$ QD655 for $10 \mathrm{~min}$ in darkness, washed and either fixed in $3.7 \%$ paraformaldehyde (PFA) on ice for $20 \mathrm{~min}$ or incubated at $37^{\circ} \mathrm{C}$ in DMEM for different periods of time before fixation. When acid treatment was applied, cells were incubated for $5 \mathrm{~min}$ (microscopy) or $2 \mathrm{~min}$ (flow cytometry) at room temperature with, $0.5 \mathrm{M} \mathrm{NaCl}, 0.1 \mathrm{M} \mathrm{Na}$-glycine $\mathrm{pH} 3.0$ and then fixed in $3.7 \%$ PFA for microscopy experiments or directly analyzed by flow cytometry.

\section{Immunofluorescence}

After overnight starvation, transfected cells were stimulated with $100 \mathrm{nM}$ rhIns, IGF-II or IGF-II-biot for 5 min, washed with cold PBS and immediately fixed in cold methanol for $30 \mathrm{~min}$ at $-20^{\circ} \mathrm{C}$, blocked with $\mathrm{PBS} /$ $0.3 \%$ Triton $\mathrm{X}-100 / 1 \% \mathrm{BSA}$ for 1 hour at $37^{\circ} \mathrm{C}$ and incubated with anti-phosphorylated-IR- $\beta$ subunit $(0.3 \mu \mathrm{g} / \mathrm{ml})$ overnight at $4^{\circ} \mathrm{C}$. The following day the samples were incubated with a secondary antibody conjugated with Alexa fluor 555 for 1 hour at $37^{\circ} \mathrm{C}$ and washed. IR activation was monitored by confocal microscopy. To study the expression of IR-B-GFP we followed the same strategy but we did not starve the cells before the assay. We used anti-IR- $\alpha$-subunit (N20 and H78) $(0.2 \mu \mathrm{g} / \mathrm{ml})$, the following day we incubated the cells with a secondary antibody conjugated with Cy3. For endocytosis immunofluorescence, HeLa cells expressing IR-B were labeled with BAC-Ins and QD655, induced internalization and fixed in $3.7 \%$ PFA. Immunofluorescences were performed with $4 \mu \mathrm{g} / \mathrm{ml}$ anti-CD63 or $1.5 \mu \mathrm{g} / \mathrm{ml}$ EEA1. 


\section{Microscopy}

Confocal laser scanning microscopy was performed with: (i) an Olympus Fluoview FV 1000 microscope with a UPLSAPO $60 \times 1.2$ NA water immersion objective. Excitation and emission filters were as follows: excitation SCFP, $405 \mathrm{~nm}$; emission SCFP, band pass (BP): 430-470 nm; excitation GFP, $488 \mathrm{~nm}$; emission GFP, BP: 505-605 nm; excitation SYFP, $515 \mathrm{~nm}$; emission SYFP, BP: 535-565 nm; excitation DAPI, $405 \mathrm{~nm}$; emission DAPI, BP: 430-470 nm; excitation QD655, 405 nm; emission QD655, BP: 655-755 nm; excitation Alexa fluor 555, $543 \mathrm{~nm}$; emission Alexa fluor 555, BP: 560$620 \mathrm{~nm}$; (ii) a Zeiss LSM 510 Meta microscope with a Plan-Apochromat $63 \times 1.4$ NA oil immersion objective. Excitation and emission filters were as follows: excitation FITC, $488 \mathrm{~nm}$; emission FITC, 510-563 nm.

We always used the sequential mode for image acquisition.

In the experiments where imaging was performed with a Zeiss LSM 510 Meta microscope we used a C-Apochromat $6 \times 1.2$ NA water immersion objective. Excitation and emission filters were as follows: excitation GFP, $488 \mathrm{~nm}$; emission GFP, BP: 500/20 nm; excitation QD655, $488 \mathrm{~nm}$ and $458 \mathrm{~nm}$; emission QD655, LP: $650 \mathrm{~nm}$.

Wide field microscopy was performed with a Zeiss Axiovert S100 with a $63 \times 1.25$ NA oil immersion objective (Zeiss), a mercury arc lamp excitation and filters suitable for GFP, Cy3 and DAPI signals. Camera: Hamamatsu Orca CCD C4742-95.

\section{Image processing}

Confocal microscope images were processed with Matlab (TU Delft, The Netherlands) and Image J (National Institutes of Health). The background of each channel (mean of empty region) was subtracted and in some cases a median filter was applied (radius: 1 pixel) only for presentation. No filter was applied in quantitative analyses. The $z$-stacks (64 frames, $0.16 \mu \mathrm{m}$ step size) were processed by deconvolution using Scientific Volume Imaging Huygens Professional Version 3.6 software, applying a Quick Maximum Likelihood Estimation (QMLE) algorithm.

\section{Internalization analysis}

For quantitative internalization experiments, we defined time " 0 min" as the end of labeling-washes, and $t=10$, 20 and 150 minutes of incubation at $37^{\circ} \mathrm{C}$.

\section{Segmentation (membrane and interior)}

Channel backgrounds (median) were subtracted. Segmentation was performed for each cell using the SYFP signal. After cell segmentation the pre-membrane was defined as the difference image of the cell and a binary erosion (iterations: 5-20; alternating connectivity); we evaluated the results visually. The pre-interior was defined as the difference between the cell and the premembrane. A $Q D_{\text {mask }}$ marked red pixels. With this mask a membrane was defined as the product of the $Q D_{\text {mask }}$ and pre-membrane, and interior as the product of the $Q D_{\text {mask }}$ and pre-interior obtained previously.

\section{Estimation of the relative amount of internalization}

Values in membrane and interior were summed for red and green channel, and also sizes were measured. To compute the relative amount of internalized red fluorescence we estimated $\mathrm{QD}_{\text {total }}$ as the sum of $\mathrm{QD}_{\text {membrane }}$ and $\mathrm{QD}_{\text {interior }}$ and we calculated for each cell the ratio $\mathrm{QD}_{\text {interior }} / \mathrm{QD}_{\text {total }}$. This “internal calibration” approach was chosen to remove the influence of the amplifier gain and the zoom factor for each image acquisition condition. The expression levels were estimated as the mean of the SYFP signal (sum of SYFP/cell size) and for the statistical analysis only cells with similar level of IRSYFP expression were considered.

\section{Colocalization analysis}

Manders coefficients and PDM graphs were performed with the Image $J$ plugin Intensity correlation analysis. The PDM graphs show the contribution of each pixel to the colocalization coefficient.

\section{Flow cytometry}

Flow cytometry was performed with a Becton Dickinson FACSAriaII. The filters, lasers and dichroic mirrors (DM) were as follow: (i) SYFP: excitation $488 \mathrm{~nm}$, DM LP: 502 $\mathrm{nm}$, emission BP: 530/30 nm; (ii) QD655: excitation 488 nm, DM LP: 655 nm, emission BP: 660/20 nm. Data analysis was performed with WinMDI Version 2.9 software. Positive events for SYFP signal were selected taking into account basal auto-fluorescence of control cells (nontransfected cells). QD655 histograms were performed with the population of events SYFP positive (transfected cells) and overlays of histograms from cells incubated at $37^{\circ} \mathrm{C}$ for 20 or $90 \mathrm{~min}$ and non-incubated cells were displayed. A geometric mean was calculated for each histogram using the WinMDI. In each histogram a marker M1 was determined including approximately $4 \%$ of the events at the initial moment $(0 \mathrm{~min})$. For each internalization period the percentage of events inside region M1 was measured and the normalization was done with respect to the initial step (0 min) (Marker/0 min).

\section{Graphical fitting}

The data for internalization experiments (microscopy and flow cytometry) were fitted by Origin 8.6 using sigmoideal logistic curve. 


\section{Statistical analysis}

The results were expressed as the mean \pm s.e.m. $p$ values were estimated using two-tailed Student's t-tests.

For supplementary methods see Additional file 7.

\section{Additional files}

Additional file 1: Figure S1. IR and IGF-IR expression in HeLa cells. mRNA from HeLa cells was reverse-transcribed and assayed by PCR (RTPCR). A. Splicing of exon 11 (36 nt) was assayed using primers that annealed in the flanking constitutive regions (i.e. exon 10 and exon 12). PCR products were analyzed by $6 \%$ PAGE and percentage of exon inclusion was quantified by densitometry. B. mRNA levels of IR and IGF-IR were assayed by RT-PCR with different amounts of CDNA. Quantification was performed by densitometry in the region where the response was linear. The results are expressed as the mean \pm s.e.m $(n=2$ independent experiments). C. PCR showing IR-B over-expressed in HeLa cells.

Additional file 2: Figure S2. Estimation of transfection efficiency. HeLa cells were transfected with pcDNA3-IR-B-GFP (A) or pcDNA3-IR-B (B) and labeled with $50 \mathrm{nM}$ BAC-Ins for $15 \mathrm{~min}$ and 1nM QD655 for 10 min. After labeling cells were imaged by confocal microscopy (Zeiss LSM 510 Meta). Scale bars: $10 \mu \mathrm{m}$. C. Total number of cells was estimated from DIC images. Transfected cells were estimated from GFP images for IR-B-GFP and from QD655 images for IR-B. Results are expressed as the mean \pm s.e. m ( $n=219$ cells for IR-VFP and $n=308$ cells for IR from at least 3 images from 3 independent experiments).

Additional file 3: Figure S3. Expression of IR-B-GFP by immunofluorescence. HeLa cells expressing IR-B-GFP were fixed in methanol and then incubated with primary antibodies against two different regions of the $\mathrm{N}$-terminus of the a-subunit of IR ( $\mathrm{N} 2 \mathrm{O}$ and H78). Secondary antibody was conjugated with Cy3. Imaging was carried out by epifluorescence microscopy (Zeiss Axiovert S100). Scale bars: $5 \mu \mathrm{m}$

Additional file 4: Figure S4. Internalization of FITC-Insulin and BACIns-SA-atto 550. A. HeLa cells over-expressing IR-B-GFP were labeled with $50 \mathrm{nM} \mathrm{BAC-Ins}$ for $15 \mathrm{~min}$ and then with $1 \mathrm{nM}$ SA-atto 550 for $10 \mathrm{~min}$ at RT. Cells were directly fixed in PFA (upper panel) or incubated at $37^{\circ} \mathrm{C}$ for 60 min before fixation (middle panel). Lower panel shows the control experiment where the cells were treated similarly but without incubation with BAC-Ins. Imaging was performed by confocal microscopy (Olympus Fluoview FV1000). Scale bars: $10 \mu \mathrm{m}$. B. HeLa cells transfected with pcDNA3-IR-B were labeled with $50 \mathrm{nM}$ FITC-insulin for $15 \mathrm{~min}$ and then directly fixed in methanol (upper panel) or incubated at $37^{\circ} \mathrm{C}$ for $75 \mathrm{~min}$ before fixation (middle panel). Lower panel shows similar experiment but in non transfected HeLa cells. Imaging was performed by confocal microscopy (Zeiss LSM 510 Meta). Scale bars: $10 \mu \mathrm{m}$.

Additional file 5: Movie S1. Visualization of IGF-II-biot-QD655 bound to IR-B-GFP and endocytosed. HeLa cells expressing IR-B-GFP were labeled in vivo with $50 \mathrm{nM}$ IGF-II-biot and $2 \mathrm{nM}$ QD655, incubated at $37^{\circ} \mathrm{C}$ for 1 hour, treated for 5 min with $0.1 \mathrm{mM} \mathrm{Na-glycine} \mathrm{pH} \mathrm{3.0,} \mathrm{NaCl} 0.5 \mathrm{M}$ and fixed in $3.7 \%$ PFA. Images were taken with a confocal microscope by acquisition of 64 z-slices with $16 \mu \mathrm{m}$ step size. Deconvolution was performed with Huygens Scientific Volume Imaging Huygens Professional Version 3.6, applying the Quick maximum likelihood estimation algorithm. The movie shows tridimensional reconstruction using the surface renderer process observed from different angles.

Additional file 6: Figure S5. Specificity of the binding of BAC-Ins and IGF-II-biot to the IR-B by flow cytometry. HeLa cells over-expressing IR-B $(A-C)$ or IR-B-SYFP ( $D$ and $E$ ) were labeled in vivo with $50 \mathrm{nM} \mathrm{BAC-Ins} \mathrm{and}$ $1 \mathrm{nM}$ QD655 (C and E) or only with $1 \mathrm{nM}$ QD655 (B and D). Cells were collected with $0.5 \mathrm{mM}$ EDTA in PBS and were analyzed by flow cytometry detecting SYFP and QD655 signals. The images inside the graphs correspond to similar experiments but analyzed by confocal microscopy (QD655 are shown in red and SYFP in green). F. Quantification of the proportion of events in the region II (see panel A) with high signal of SYFP (transfected cells) and high signal of QD655 (insulin or IGFII binding). We normalized this value to the proportion obtained for the cells only incubated with QD655 without biotinylated ligand. G. HeLa cells expressing IR-B-SYFP were labeled in vivo with $50 \mathrm{nM} \mathrm{IGF-II-biot} \mathrm{and}$ $1 \mathrm{nM}$ QD655 at room temperature and were treated (or not) with acid (0.1 M Na-glycine $\mathrm{pH} \mathrm{3,0.5} \mathrm{M} \mathrm{NaCl)} \mathrm{for} 2$ min. After washing with PBS, cells were collected with $0.5 \mathrm{mM}$ EDTA in PBS and analyzed by flow cytometry detecting SYFP and QD655 signals. The bar graph shows the quantification of the ratio between the events inside region II and the events inside region $(\|+\mid \mathrm{V})$. Asterisks indicate significant differences ( $p \leq 0.001 ; n=3$ independent experiments).

Additional file 7. Supplementary methods.

\section{Abbreviations}

BAC-Ins: Biotin amido caproyl insulin; BP: Band-pass; BSA: Bovine serum albumin; DM: Dichroic mirror; EEA1: Early endosomes marker; EGF: Epidermal growth factor; EV: Empty vector; FBS: Fetal bovine serum; GFP: Enhanced green fluorescent protein; IGF: Insulin like growth factor; IGF-II-

biot: Biotinylated IGF-II; IGF-IR: Insulin like growth factor I receptor; IR: Insulin receptor; IR-A: Insulin receptor isoform A; IR-B: Insulin receptor isoform B; M: Manders coefficient; PDM: Differences from the mean; PFA: Paraformaldehyde; QD: Quantum dot; rhlns: Recombinant human insulin; QMLE: Quick maximum likelihood estimation algorithm; SA: Streptavidin; SCFP: Super cyan fluorescent protein; s.e.m: Standard error of the mean; SYFP: Super yellow fluorescent protein; VFP: Visible fluorescent protein.

\section{Competing interests}

The authors declare that they have no competing interests.

\section{Authors' contributions}

JG conceived, designed and performed the experiments and deconvolution analysis, analyzed the data and wrote the paper. LSB designed and performed experiments. FFG carried out deconvolution analysis. APS sequenced and analyzed all DNA plasmids. LG revised the manuscript critically. EJE conceived and designed the experiments, analyzed the data and wrote the paper. FCL conceived and designed the experiments, analyzed the data and wrote the paper. All authors read and approved the final manuscript with the exception of the deceased, Elizabeth Jares Erijman.

\section{Acknowledgements}

Elizabeth Jares-Erijman died during the preparation of this manuscript and we dedicate it to her memory. J.G. was a recipient of a CONICET fellowship and was awarded a short term EMBO fellowship. This work was supported by the Max Planck Society, University of Buenos Aires, CONICET (Argentina), CONICET (Argentina), and ANPCyT (Argentina). We thank Laboratorios BETA (Buenos Aires, Argentina) for providing rhlns. We thank Dr. Omar Coso (IFIBYNE, Argentina) for providing anti-ERK2 antibody and pAP1-Luc reporter plasmid.

\section{Author details}

'Departamento de Química Biológica, Facultad de Ciencias Exactas y Naturales (FCEN), Universidad de Buenos Aires (UBA), IQUIBICEN, CONICET, Buenos Aires, Argentina. ${ }^{2}$ Departamento de Química Orgánica, FCEN, UBA CIHIDECAR, CONICET, Buenos Aires, Argentina. Instituto de Estudios de la Inmunidad Humoral (IDEHU), CONICET-UBA y Cátedra de Inmunología Facultad de Farmacia y Bioquímica, UBA, Buenos Aires, Argentina. ${ }^{4}$ Laboratory of Cellular Dynamics, Max Planck Institute for Biophysical Chemistry, Göttingen, Germany. ${ }^{5}$ Departamento de Ciencias Básicas, Universidad Nacional de Luján, Argentina. ${ }^{6}$ Present address: Department of Pathology and Immunology, Baylor College of Medicine, One Baylor Plaza, Houston, TX 77030, USA.

Received: 22 September 2012 Accepted: 14 December 2012 Published: 11 March 2013

\section{References}

1. Chan SJ, Steiner DF: Insulin through the ages: phylogeny of a growth promoting and metabolic regulatory hormone. Am Zool 2000, 40:213-222.

2. Kimura KD, Tissenbaum HA, Liu Y, Ruvkun G: daf-2, an insulin receptor-like gene that regulates longevity and diapause in Caenorhabditis elegans. Science 1997, 277:942-946. 
3. Efstratiadis A: Genetics of mouse growth. Int J Dev. Biol 1998, 42:955-976.

4. Tissenbaum HA, Ruvkun G: An insulin-like signaling pathway affects both longevity and reproduction in Caenorhabditis elegans. Genetics 1998, 148:703-717.

5. Brogiolo W, Stocker H, Ikeya T, Rintelen F, Fernandez R, et al: An evolutionarily conserved function of the Drosophila insulin receptor and insulin-like peptides in growth control. Curr Biol 2001, 11:213-221.

6. Nakae J, Kido Y, Accili D: Distinct and overlapping functions of insulin and IGF-I receptors. Endocr Rev 2001, 22:818-835.

7. Saltiel AR, Kahn CR: Insulin signalling and the regulation of glucose and lipid metabolism. Nature 2001, 414:799-806.

8. Holzenberger M, Dupont J, Ducos B, Leneuve P, Geloen A, et al: IGF-1 receptor regulates lifespan and resistance to oxidative stress in mice. Nature 2003, 421:182-187.

9. Nef S, Verma-Kurvari S, Merenmies J, Vassalli JD, Efstratiadis A, et al: Testis determination requires insulin receptor family function in mice. Nature 2003, 426:291-295.

10. Fernández R, Tabarini D, Azpiazu N, Frasch M, Schlessinger J: The Drosophila insulin receptor homolog: a gene essential for embryonic development encodes two receptor isoforms with different signaling potential. EMBO J 1995, 14:3373-3384.

11. Pashmforoush M, Chan SJ, Steiner DF: Structure and expression of the insulin-like peptide receptor from amphioxus. Mol Endocrinol 1996, 10:857-866

12. Ruvkun G, Hobert O: The taxonomy of developmental control in Caenorhabditis elegans. Science 1998, 282:2033-2041.

13. Ebina $Y, E$ Ellis $L$, Jarnagin $K$, Edery $M, G$ raf $L$, et al: The human insulin receptor cDNA: the structural basis for hormone-activated transmembrane signalling. Cell 1985, 40:747-758.

14. Ullrich A, Bell JR, Chen EY, Herrera R, Petruzelli LM, et al: Human insulin receptor and its relationship to the tyrosine kinase family of oncogenes. Nature 1985, 313:756-761.

15. Ullrich A, Gray A, Tam AW, Yang-Feng T, Tsubokawa M, et al: Insulin-like growth factor I receptor primary structure: comparison with insulin receptor suggests structural determinants that define functional specificity. EMBO J 1986, 5:2503-2512

16. Shier $P$, Watt VM: Primary structure of a putative receptor for a ligand of the insulin family. J Biol Chem 1989, 264:14605-14608.

17. De Pirro R, Forte F, Bertoli A, Greco AV, Lauro R: Changes in insulin receptors during oral contraception. J Clin Endocrinol Metab 1991, 52:29-33.

18. Mosthaf L, Vogt B, Haring HU, Ullrich A: Altered expression of insulin receptor types $A$ and $B$ in the skeletal muscle of non-insulin-dependent diabetes mellitus patients. Proc Natl Acad Sci USA 1991, 88:4728-4730.

19. Kellerer M, Sesti G, Seffer E, Obermaier-Kusser B, Pongratz DE, et al: Altered pattern of insulin receptor isotypes in skeletal muscle membranes of type 2 (noninsulin-dependent) diabetic subjects. Diabetologia 1993, 36:628-632.

20. Savkur RS, Philips AV, Cooper TA: Aberrant regulation of insulin receptor alternative splicing is associated with insulin resistance in myotonic dystrophy. Nat Genet 2001, 29:40-47.

21. Yakar S, Liu JL, Stannard B, Butler A, Accili D, et al: Normal growth and development in the absence of hepatic insulin-like growth factor I. Proc Natl Acad Sci USA 1999, 96:7324-7329.

22. Sutter NB, Bustamante CD, Chase K, Gray MM, et al: A single IGF1 allele is a major determinant of small size in dogs. Science 2007, 316:112-115.

23. Guevara-Aguirre J, Balasubramanian P, Guevara-Aguirre M, Wei M, Madia F, et al: Growth hormone receptor deficiency is associated with a major reduction in Pro-aging signaling, cancer, and diabetes in humans. Sci Trans/ Med 2011, 3:70ra13.

24. Whittaker J, Groth AV, Mynarcik DC, Pluzek L, Gadsboll VL, Whittaker LJ: Alanine scanning mutagenesis of a type 1 insulin-like growth facto receptor ligand binding site. J Biol Chem 2001, 276:43980-43986.

25. De Meyts P: Insulin and its receptor: structure, function and evolution. Bioessays 2004, 26:1351-1362

26. Papa V, Gliozzo B, Clark GM, McGuire WL, Moore D, et al: Insulin-like growth factor-I receptors are overexpressed and predict a low risk in human breast cancer. Cancer Res 1993, 53:3736-3740.

27. Pandini G, Vigneri R, Costantino A, Frasca F, Ippolito A, et al: Insulin and insulin-like growth factor-I (IGF-I) receptor overexpression in breast cancers leads to insulin/IGF-I hybrid receptor overexpression: evidence for a second mechanism of IGF-I signaling. Clin Cancer Res 1999, 5:1935-1944.

28. Vella V, Sciacca L, Pandini G, Mineo R, Squatrito S, et al: The IGF system in thyroid cancer: new concepts. Mol Pathol 2001, 54:121-124.

29. Kasuga M, Fujita-Yamaguchi Y, Blithe DL, White MF, Kahn CR: Characterization of the insulin receptor kinase purified from human placental membranes. J Biol Chem 1983, 258:10973-10980.

30. Soos MA, Siddle K: Immunological relationships between receptors for insulin and insulin-like growth factor I. Evidence for structural heterogeneity of insulin-like growth factor I receptors involving hybrids with IRs. Biochem J 1989, 263:553-563.

31. Soos MA, Whittaker J, Lammers R, Ullrich A, Siddle K: Receptors for insulin and insulin-like growth factor-I can form hybrid dimers. Characterisation of hybrid receptors in Transfected cells. Biochem J 1990, 270:383-390.

32. Soos MA, Field CE, Siddle K: Purified hybrid insulin/insulin-like growth factor-I receptors bind insulin-like growth factor-l, but not insulin, with high affinity. Biochem J 1993, 290:419-426.

33. Yamaguchi Y, Flier JS, Yokota A, Benecke H, Backer JM, Moller DE: Functional properties of two naturally occurring isoforms of the human insulin receptor in Chinese hamster ovary cells. Endocrinology 1991, 129:2058-2066.

34. Benyoucef S, Surinya KH, Hadaschik D, Siddle K: Characterization of insulin/ IGF hybrid receptors: contributions of the insulin receptor L2 and Fn1 domains and the alternatively spliced exon 11 sequence to ligand binding and receptor activation. Biochem J 2007, 403:603-613.

35. Pandini G, Frasca F, Mineo R, Sciacca L, Vigneri R, Belfiore A: Insulin/insulinlike growth factor I hybrid receptors have different biological characteristics depending on the insulin receptor isoform involved. J Biol Chem 2002, 277:39684-39695.

36. Denley A, Bonython ER, Booker GW, Cosgrove LJ, Forbes BE, et al: Structural determinants for high-affinity binding of insulin-like growth factor II to insulin receptor (IR)-A, the exon 11 minus isoform of the IR. Mol Endocrinol 2004, 18:2502-2512.

37. Sciacca L, Costantino A, Pandini G, Mineo R, Frasca F, et al: Insulin receptor activation by IGF-II in breast cancers: evidence for a new autocrine/ paracrine mechanism. Oncogene 1999, 18:2471-2479.

38. Pandini G, Medico E, Conte E, Sciacca L, Vigneri R, Belfiore A: Differential gene expression induced by insulin and insulin-like growth factor-II through the insulin receptor isoform A. J Biol Chem 2003, 278:42178-42189.

39. Pastore S, Mascia F, Mariotti F, Dattilo C, Mariani V, Girolomoni G: ERK1/2 regulates epidermal chemokine expression and skin inflammation. J Immunol 2005, 174:5047-5056.

40. Lidke DS, Nagy P, Heintzmann R, Arndt-Jovin DJ, Post J, Grecco H, et al: Quantum dot ligands reveal EGFR dynamics in living cells. Nat Biotechnol 2004, 22:198-203.

41. Draznin B, Trowbridge M, Ferguson L: Quantitative studies of the rate of insulin internalization in isolated rat hepatocytes. Biochem J 1984, 218:307-312.

42. Hachiya HL, Takayama S, White MF, King GL: Regulation of insulin receptor internalization in vascular endothelial cells by insulin and phorbol ester. J Biol Chem 1987, 262:6417-6424.

43. Formisano P, Najjar SM, Gross CN, Philippe N, Oriente F, Kern-Buell CL, Accili $D$, Gorden P: Receptor-mediated internalization of insulin. Potential role of pp120/HA4, a substrate of the insulin receptor kinase. J Biol Chem 1995, 270:24073-24077.

44. Knutson VP: Ligand-independent internalization and recycling of the insulin receptor. Effects of chronic treatment of 3T3-C2 fibroblasts with insulin and dexamethasone. J Biol Chem 1992, 267:931-937.

45. Morcavallo A, Genua M, Palummo A, Kletvikova E, Jiracek J, Brzozowski AM, Iozzo RV, Belfiore A, Morrione A: Insulin and Insulin-like Growth Factor II Differentially regulate endocytic sorting and stability of insulin receptor isoform A. J Biol Chem 2012, 287:11422-11436.

46. Sorkin A, Eriksson A, Heldin CH, Westermark B, Claesson-Welsh L: Pool of ligand bound platelet-derived growth factor beta-receptors remain activated and tyrosine phosphorylated after internalization. J Cell Physiol 1993, 156:373-382

47. Bergeron JJ, Di Guglielmo GM, Baass PC, Authier F, Posner Bl: Endosomes, receptor tyrosine kinase internalization and signal transduction. Biosci Rep 1995, 15:411-418. 
48. Biener $Y$, Feinstein R, Mayak M, Kaburagi Y, Kadowaki T, Zick Y: Annexin II is a novel player in insulin signal transduction. Possible association between annexin II phosphorylation and insulin receptor internalization. J Biol Chem 1996, 271:29489-29496.

49. Grimes ML, Zhou J, Beattie EC, Yuen EC, Hall DE, et al: Endocytosis of activated TrkA: evidence that nerve growth factor induces formation of signaling endosomes. J Neurosci 1996, 16:7950-7964.

50. Ceresa BP, Kao AW, Santeler SR, Pessin JE: Inhibition of clathrin mediated endocytosis selectively attenuates specific insulin receptor signal transduction pathways. Mol Cell Biol 1998, 18:3862-3870.

51. Parpal S, Karlsson M, Thorn H, Straálfors P: Cholesterol depletion disrupts caveolae and insulin receptor signaling for metabolic control via insulin receptor substrate- 1 , but not for mitogen-activated protein kinase control. J Biol Chem 2001, 276:9670-9678.

52. Hamer I, Foti M, Emkey R, Cordier-Bussat M, Philippe J, et al: An arginine to cysteine (252) mutation in insulin receptors from a patient with severe insulin resistance inhibits receptor internalization but preserves signalling events. Diabetologia 2002, 45:657-667.

53. Jensen M, Hansen B, De Meyts $P$, Schäffer L, Ursø B: Activation of the insulin receptor by insulin and a synthetic peptide leads to divergent metabolic and mitogenic signaling and responses. J Biol Chem 2007, 282:35179-35186.

54. Uhles S, Moede T, Leibiger B, Berggren PO, Leibiger IB: Selective gene activation by spatial segregation of insulin receptor $B$ signaling. FASEB $J$ 2007, 21:1609-1621.

55. Jensen M, De Meyts P: Molecular mechanisms of differential intracellular signaling from the insulin receptor. Vitam Horm 2009, 80:51-75.

56. Hansen BF, Danielsen GM, Drejer K, Sørensen AR, Wiberg FC, et al: Sustained signalling from the insulin receptor after stimulation with insulin analogues exhibiting increased mitogenic potency. Biochem $J$ 1996, 315(Pt 1):271-279.

57. Ish-Shalom D, Christoffersen CT, Vorwerk P, Sacerdoti-Sierra N, Shymko RM, et al: Mitogenic properties of insulin and insulin analogues mediated by the insulin receptor. Diabetologia 1997, 2(Suppl 40):S25-S31.

58. De Meyts P, Shymko RM: Timing-dependent modulation of insulin mitogenic versus metabolic signalling. Novartis Found Symp 2000, 227:46-57.

59. Kurtzhals P, Schäffer L, Sørensen A, Kristensen C, Jonassen I, et al: Correlations of receptor binding and metabolic and mitogenic potencies of insulin analogs designed for clinical use. Diabetes 2000, 49:999-1005.

doi:10.1186/1478-811X-11-18

Cite this article as: Giudice et al:: Insulin and insulin like growth factor II endocytosis and signaling via insulin receptor B. Cell Communication and Signaling 2013 11:18.

\section{Submit your next manuscript to BioMed Central and take full advantage of:}

- Convenient online submission

- Thorough peer review

- No space constraints or color figure charges

- Immediate publication on acceptance

- Inclusion in PubMed, CAS, Scopus and Google Scholar

- Research which is freely available for redistribution 